\title{
ANALISIS HARGA ECERAN GULA KRISTAL PUTIH INDONESIA
}

\author{
Indonesian Plantation White Sugar Retail Price Analysis
}

\author{
Aditya Arief Rachmadhan, Nunung Kusnadi, Andriyono Kilat Adhi \\ Fakultas Ekonomi dan Manajemen, Institut Pertanian Bogor, \\ JI. Raya Darmaga, Kampus IPB Darmaga, Bogor 16680, Jawa Barat, Indonesia \\ Email: aditcakep.tq@gmail.com
}

Naskah diterima: 10/04/2019; Naskah direvisi: 14/01/2020; Disetujui diterbitkan: 14/05/2020;

Dipublikasikan online: 15/07/2020

\begin{abstract}
Abstrak
Salah satu upaya pemerintah untuk menyediakan gula kristal putih dengan harga terjangkau di tingkat konsumen adalah dengan menetapkan harga acuan penjualan (HAP). Meskipun demikian, harga gula kristal putih di tingkat konsumen terus meningkat dari tahun ke tahun. Tujuan penelitian ini adalah untuk menganalisis faktor yang memengaruhi pembentukan harga eceran gula kristal putih secara komprehensif. Penelitian ini menggunakan model ekonometrika (dibangun berdasarkan data time series bulanan dari tahun 2012 hingga tahun 2017, terdiri dari 13 persamaan dan diestimasi menggunakan metode 2 SLS) dan simulasi kebijakan. Hasil menunjukkan bahwa faktor yang berpengaruh secara signifikan pada harga eceran gula kristal putih adalah konsumsi gula kristal putih, impor gula kebutuhan industri, harga gula dunia, harga beras di tingkat konsumen dan harga eceran gula kristal putih periode sebelumnya. Harga beras di tingkat konsumen merupakan variabel yang paling berpengaruh terhadap pembentukan harga gula kristal putih. Skenario kebijakan yang dapat menurunkan harga eceran gula kristal putih adalah penerapan HAP gula kristal putih yang terintegrasi dengan kenaikan impor gula kristal putih.
\end{abstract}

Kata kunci: Harga Gula, Model Ekonometrika, Harga Acuan Penjualan (HAP)

\begin{abstract}
One of the government's efforts to provide plantation white sugar at low prices at the consumer level is to set a reference sales price (HAP). Nevertheless, plantation white sugar consumer prices continue to increase. The purpose of this study was to analyze the factors that influence plantation white sugar consumer prices. This study uses an econometrics model (build from monthly time series data from 2012 until 2017, consist of 13 equations and estimated using the 2SLS method) and policy simulation. The results, an decrease in HAP, has no impact on plantation white sugar consumer prices. An increase in plantation white sugar imports can reduce the plantation white sugar consumer prices. The results show that the factors that significantly influence the retail price of plantation white sugar are consumption of plantation white sugar, import of industrial sugar, world sugar prices, rice prices at the consumer level, and retail prices of plantation white sugar in the previous periods. The price of rice at the consumer level is the most influential variable. The policy scenario that can reduce the retail price of white crystal sugar is the application of white crystal sugar HAP that is integrated with the increase in white crystal sugar imports.
\end{abstract}

Keywords: Sugar Price, Econometric Model, Reference Sales Price (HAP)

JEL Classification: Q02, Q11, Q18

\section{PENDAHULUAN}

Gula kristal putih adalah gula yang digunakan untuk konsumsi rumah tangga
(Fajrin et al., 2015). Gula (termasuk gula kristal putih) merupakan salah satu barang kebutuhan pokok Indonesia 
sesuai Peraturan Presiden Republik Indonesia (Perpres RI) Nomor 71 Tahun 2015. Berdasarkan peraturan tersebut, Pemerintah Pusat dan Pemerintah Daerah betanggung jawab dalam penyediaan dan gula kristal putih dalam jumlah yang memadai dan harga yang terjangkau. Hal ini menjadikan gula kristal putih merupakan komoditas strategis di Indonesia (Lestari et al., 2016).
Namun, produksi gula kristal putih dalam negeri masih belum mampu memenuhi kebutuhan konsumsi gula Indonesia (Gambar 1). Defisit gula Indonesia menyebabkan tingginya harga eceran gula kristal putih di tingkat konsumen. Dibandingkan dengan harga gula mentah dan rafinasi, harga gula kristal putih memiliki harga pasar yang tertinggi (Saputri \& Respatiadi, 2018).

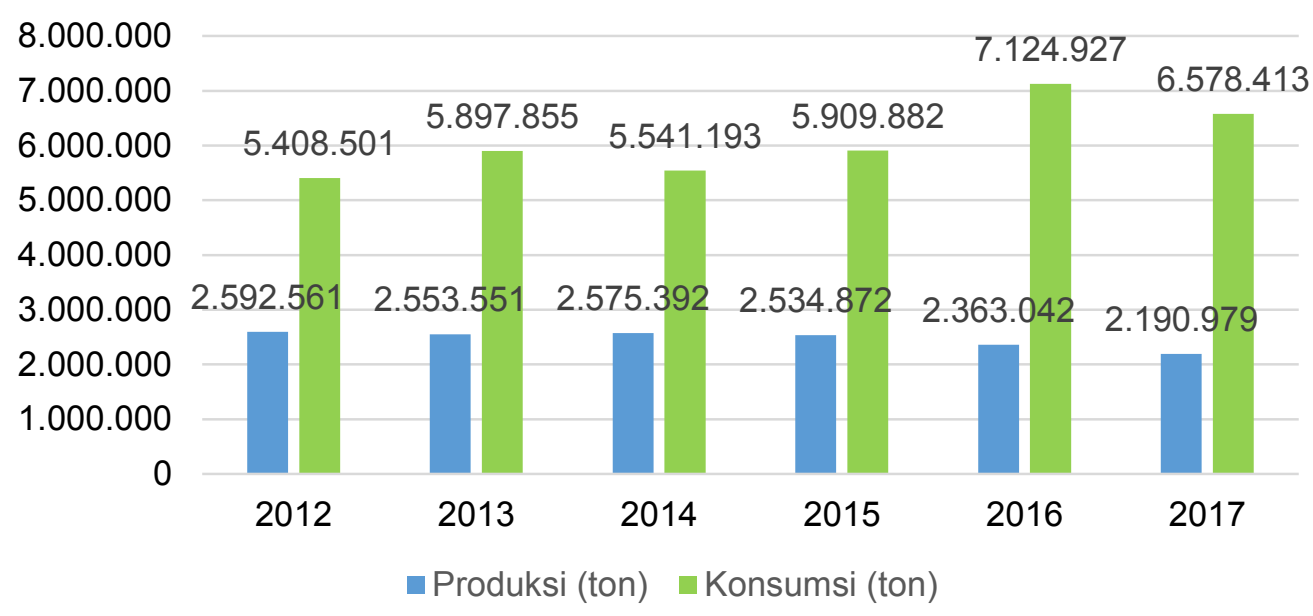

\section{Gambar 1. Produksi dan Konsumsi Gula Indonesia Tahun 2012-2017}

Sumber : BPS (2014b), BPS (2015b), BPS (2016b), BPS (2017b), BPS (2018b), ITC (2019b), ITC (2019a), ITC (2019c), ITC (2019d), ITC (2019e), ITC (2019f) dan ITC (2019g) (diolah)

Pemerintah berupaya agar gula kristal putih di tingkat konsumen tersedia dengan harga yang terjangkau. Harga yang terjangkau menjadi indikator keterjangkauan pangan, yang ditentukan oleh harga eceran yang harus dibayar konsumen (masyarakat) (Erwidodo, 2015). Berbagai upaya dilakukan pemerintah untuk menjamin kestabilan harga eceran gula kristal putih agar tidak menimbulkan gejolak di masyarakat (Susilo \& Yuniati, 2016).

Indonesia bukan satu-satunya negara yang mengendalikan harga eceran gula (Sayaka \& Adhie, 2016). Tugas dan kewenangan Pemerintah untuk menjaga stabilitas pasokan dan harga gula kristal putih di tingkat 
konsumen diatur berdasarkan UndangUndang Nomor 18 Tahun 2012. Salah satu upaya untuk melaksanakannya adalah dengan menetapkan harga acuan penjualan (HAP) di tingkat konsumen.

HAP gula kristal putih menjadi harga acuan (referensi) penjualan di tingkat konsumen dengan mempertimbangkan struktur biaya yang wajar. Berdasarkan Perpres RI Nomor 71 Tahun 2015, HAP barang kebutuhan pokok secara nasional ditetapkan oleh menteri. Penetapan HAP gula kristal putih di Indonesia diatur sejak tahun 2016 melalui Peraturan Menteri Perdagangan RI Nomor 63/MDAG/PER/9/2016. Tujuan penetapan HAP gula kristal putih adalah menjamin ketersediaan, stabilitas dan kepastian harga untuk komoditas gula kristal putih. HAP juga menjadi acuan bagi Pemerintah untuk melakukan intervensi langsung pada pasar. Ketika harga eceran gula kristal putih di tingkat konsumen berada di atas HAP, Menteri dapat menugaskan BUMN terkait untuk melakukan penjualan gula kristal putih di tingkat konsumen sesuai dengan HAP yang bertujuan menurunkan harga gula eceran kristal putih. Pelaksanaanya diatur berdasarkan Perpres RI Nomor 48 Tahun 2016. Intervensi langsung pemerintah telah menjadi mekanisme utama menstabilkan harga pangan di negara berkembang (Erwidodo, 2015).

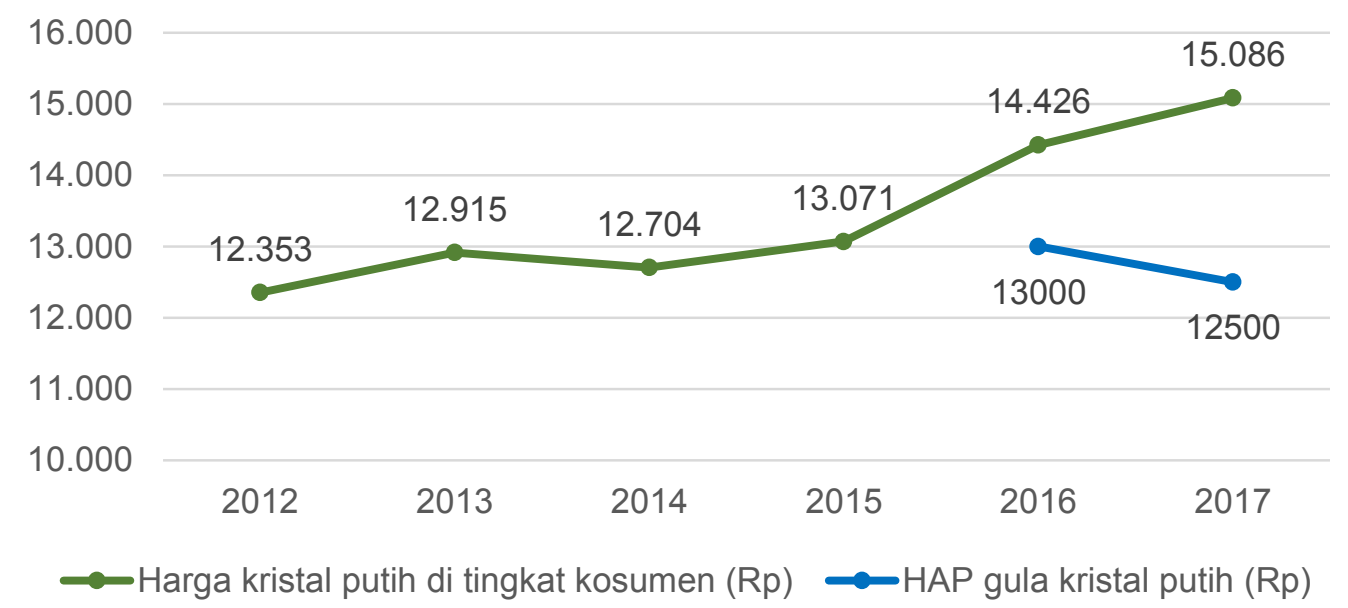

\section{Gambar 2. Perkembangan Harga Gula Kristal Putih di Tingkat Konsumen dan HAP Gula Kristal Putih}

Sumber : BPS (2013), BPS (2014a), BPS (2015a), BPS (2016a), BPS (2017a), BPS (2018a), dan Kementerian Perdagangan Republik Indonesia (2019) 
Faktanya, harga gula kristal putih di tingkat konsumen terus meningkat dari tahun ke tahun (Gambar 1). Kenaikan harga eceran gula kristal putih seiring dengan perkembangan harga lelang gula kristal putih, yakni harga gula kristal putih di tingkat petani (produsen). Periode 2012-2017, tercatat harga lelang gula kristal putih meningkat sebesar 3,9\%. Namun, harga eceran gula kristal putih meningkat hingga sebesar $22,124 \%$.

Meskipun kebijakan HAP telah ditetapkan sejak tahun 2016 dan harga HAP diturunkan pada tahun 2017 (melalui Permendag RI Nomor 27/MDAG/PER/5/2017), harga eceran gula kristal putih terus mengalami kenaikan. Perkembangan harga gula kristal putih di tingkat konsumen justru menunjukkan pertumbuhan yang berbanding terbalik dengan HAP yang telah ditetapkan.

Kondisi tersebut menunjukkan bahwa harga eceran gula kristal putih tidak lepas dari berbagai faktor yang secara simultan memengaruhinya. Analisis harga eceran gula kristal putih perlu dilakukan secara komprehensif. Pembahasan dalam ekonomi tidak dapat terpisah, dimana setiap variabel ekonomi (dalam penawaran, permintaan dan harga) saling terhubung secara simultan. Tujuan penelitian ini adalah untuk menganalisis faktor yang memengaruhi pembentukan harga eceran gula kristal putih secara komprehensif.

\section{METODE}

\section{Kerangka Teori dan Spesifikasi Model}

Ekonomi gula kristal putih terdiri dari sisi permintaan, penawaran dan harga yang saling terkait (Sa'diyah et al., 2014). Interaksi antara permintaan dan penawaran menghasilkan harga keseimbangan. Guna menganalisis pembentukan harga eceran gula kristal putih, perlu dilakukan analisis secara komprehensif, setiap variabel ekonomi saling terhubung secara simultan. Sehingga perlu diketahui elemen-elemen yang membentuk sisi penawaran, permintaan dan harga gula kristal putih.

Pembentuk sisi penawaran gula kristal putih berasal dari produksi gula kristal putih perkebunan tebu rakyat, perkebunan besar negara dan perkebunan besar swasta. Produksi gula kristal putih perkebunan tebu rakyat dan perkebunan besar negara dijual melalui lelang, dengan harga yang berlaku adalah harga lelang (Pusat Kebijakan Perdagangan Dalam Negeri, 2015). Produksi gula kristal putih perkebunan besar negara juga dijual langsung ke konsumen. Sedangkan produksi gula kristal putih perkebunan 
besar swasta dijual langsung ke konsumen, dengan harga yang berlaku adalah harga eceran. Harga gula kristal putih merupakan faktor yang menentukan produksi gula kristal putih. Faktor lain yang menentukan produksi gula kristal putih adalah kebijakan pemerintah (diantaranya subsdi) (Rahardja \& Manurung, 2014); dan faktor produksi yang meliputi pupuk dan tenaga kerja (Pakpahan, 2017).

Total produksi gula kristal putih Indonesia masih belum dapat memenuhi seluruh kebutuhan gula Indonesia. Kekurangan pasokan gula dalam negeri adalah faktor utama bagi Indonesia untuk terus melakukan impor gula (Rahman et al., 2018). Melalui perdagangan impor, pemerintah dapat menurunkan harga gula kristal putih dalam negeri mendekati harga dunia. Produsen dalam negeri jelas dirugikan karena harga yang diperoleh lebih rendah. Sebaliknya konsumen dalam negeri mendapatkan harga yang lebih murah (Mankiw, 2019). Namun, impor gula kristal putih Indonesia jumlahnya sangatlah terbatas.

Permintaan gula kristal putih Indonesia berasal konsumsi rumah tangga. Pemerintah memberikan batasan pasar untuk perdagangan gula kristal putih dalam negeri berdasarkan
Keputusan Menteri Perindustrian dan Perdagangan Nomor 334 Tahun 2004. Faktor yang menentukan besarnya jumlah permintaan gula kristal putih adalah harga eceran, jumlah penduduk dan pertumbuhan ekonomi (Yusuf et al., 2010).

Penawaran dan permintaan gula kristal putih terhubung oleh harga gula kristal putih. Harga lelang dan harga eceran saling memengaruhi dalam pembentukan harga gula kristal putih (Susila \& Sinaga, 2005). Pemerintah juga melakukan kebijakan harga pembelian pemerintah (HPP) pada sebagai harga acuan lelang di tingkat produsen, dan harga acuan penjualan (HAP) pada harga eceran di tingkat konsumen (Nuryati et al., 2019).

Kebijakan harga gula kristal putih dilakukan mengingat gula kristal putih merupakan barang kebutuhan pokok (Perpres RI Nomor 71 Tahun 2015). Harga pangan pokok berfluktuasi dengan cepat dan memengaruhi perdagangan barang lainnya (Lakollo, 2015). Kebijakan HPP dan HAP tidak ditetapkan sebagai harga dasar dan harga tertinggi namun sebagai harga acuan (Permendag RI Nomor 27/MDAG/PER/5/2017).

Keterkaitan antara penawaran, permintaan dan harga gula kristal putih 
dibentuk dalam model ekonometrika penawaran dan permintaan gula kristal putih Indonesia. Spesifikasi model dikembangkan berdasarkan hubungan antara penawaran, permintaan dan harga gula kristal putih (digambarkan pada Gambar 2). Model penawaran dan permintaan gula kristal putih Indonesia terdiri dari tiga blok (blok produksi, blok konsumsi, dan blok harga), dengan spesifikasi sebagai berikut:

a. Struktur Blok Penawaran

$$
\begin{aligned}
& I S P Q_{t}=S H P Q_{t}+G O P Q_{t}+P R P Q_{t} \\
& S H P Q_{t}=S H H A_{t}{ }^{*} S H Y S_{t} \\
& \mathrm{SHHA}_{t}=\mathrm{a}_{0}+\mathrm{a}_{1} \mathrm{ISFP}_{\mathrm{t} 12}+\mathrm{a}_{2} \mathrm{ILWP}_{\mathrm{t} 12}+\mathrm{a}_{3} \\
& \left(\frac{\text { ILWPt }}{\text { ISCPt }^{2}}\right)+\mathrm{a}_{4} \mathrm{IRFP}_{\mathrm{t}-12}+\mathrm{a}_{5} \mathrm{ICFP}_{\mathrm{t}-12} \\
& +a_{6} \mathrm{SHHA}_{\mathrm{t}-12}+\mu_{1} \\
& S H Y S_{t}=b_{0}+b_{1}\left(\frac{I L W P t}{I S C P t}\right)+b_{2} I S F P_{t 12}+b_{3} I U S P_{t} \\
& 11+b_{4} \text { ISFA }_{t-11}+b_{5}\left(S H H A_{t}-S H H A_{t-12}\right) \\
& +b_{6} \mathrm{SHYS}_{\mathrm{t}-12}+\mu_{2} \\
& \mathrm{GOPQ}=\mathrm{GOHA}_{\mathrm{t}}{ }^{*} \mathrm{GOYS}_{\mathrm{t}} \\
& \mathrm{GOHA}_{\mathrm{t}}=\mathrm{c}_{0}+\mathrm{c}_{1} I S F P_{\mathrm{t} 12}+\mathrm{c}_{2} I S C P_{\mathrm{t} 12}+\mathrm{c}_{3} I L W P_{\mathrm{t}} \\
& { }_{12}+\mathrm{C}_{4} \mathrm{GOHA}_{\mathrm{t}-12}+\mu_{3} \\
& \text { GOYS }_{t}=d_{0}+d_{1}\left(\frac{\text { ISFPt }}{\text { ILWPt }}\right)+d_{2} I S C P_{t-12}+ \\
& d_{3}\left(\text { IUPP:12-IUPP:11) }+d_{4}\left(G O H A-G O H A_{12}\right)\right. \\
& +\mathrm{d}_{5} \mathrm{GOPQ}_{\mathrm{t}-12}+\mu_{4} \\
& P R P Q_{t}=P R H A_{t}{ }^{*} P R Y S_{t} \\
& P R H A_{t}=e_{0}+e_{1} I S C P_{t-12}+e_{2}\left(I L W P_{t}-I L W P_{t-12}\right) \\
& +e_{3} \text { PRHA }_{\mathrm{t}-12}+\mu_{5}
\end{aligned}
$$

PRYS $_{t}=f_{0}+f_{1} I L W P_{t}+f_{2} I S C P_{t-12}+$ $f_{3}\left(U P P_{E 12}-I U F P_{111}\right)+f_{4}\left(P R H A-P R H A_{* 12}\right)$ $+f_{5} \mathrm{PRYS}_{\mathrm{t}-12}+\mu_{6}$

b. Struktur Blok Permintaan $I S C Q_{t}=g_{0}+g_{1} I S C P_{t-1}+g_{2} I_{G P C}+$ $g_{3} I N P O_{t}+g_{4} I R C P_{t}+g_{5} I S M Q_{t-1}$ $+\quad g_{6} I S C Q_{t-1}+g_{7} I S C Q_{t-}$ $12+\mu 7$

c. Struktur Blok Harga $I S C P_{t}=h_{0}+h_{1}\left(I_{S F P}-I S F P_{t-12}\right)+h_{2} D_{t A P} 1_{t}$ $+h_{3}$ DHAP2 $_{t}+h_{3} I_{1 S C Q_{t-1}}+h_{4}$ ISCQ $_{t-}$ ${ }_{12}+h_{5} I S P Q_{t-1}+h_{6} I S M Q_{t-1}+h_{7}$ $I I S M_{t-1}+h_{8} W S_{S P}+h_{9} I R C P_{t}+h_{10}$ $P O C P_{t}+h_{11} I S C P_{t-1}+h_{12} I S C P_{t-12}$ $+\mu_{8}$

$I S F P_{t}=i_{0}+i_{1} I S C P_{t}+i_{2} H_{P P}+i_{3}(S H P Q t$ $+\mathrm{GOPQt})+\mathrm{i}_{4}\left(\mathrm{SHPQ}_{\mathrm{t}-1}+\mathrm{GOPQt}\right.$ 1) + is ISCQt-1 + i6 ISMQt + iz IISMt$1+\quad \mathrm{BWOSP}_{\mathrm{t}}+\mathrm{i}_{\mathrm{g}} \mathrm{LWP}+\mathrm{i}_{1}(\mathrm{IUPP}$ $12-I U F P_{t-11}+i_{11} I S F P_{t-1}+i_{12} I S F P_{t-12}$ $+\mu 9$

keterangan:

ISPQ =Produksi gula kristal putih (ton) $S H P Q=$ Produksi gula kristal putih perkebunan tebu rakyat (ton)

GOPQ=Produksi gula kristal putih perkebunan besar negara (ton) $P R P Q=$ Produksi gula kristal putih perkebunan besar swasta (ton)

SHYS =Produktivitas gula kristal putih perkebunan tebu rakyat (ton/ha) GOYS=Produktivitas gula kristal putih perkebunan besar negara (ton/ha) 
PRYS $=$ Produktivitas gula kristal putih perkebunan besar swasta (ton/ha)

SHHA =Luas areal panen perkebunan tebu rakyat (ha)

$\mathrm{GOHA}=$ Luas areal panen perkebunan besar negara (ha)

PRHA =Luas areal panen perkebunan besar swasta (ha)

ISFP =Harga riil lelang gula kristal putih $(\mathrm{Rp} / \mathrm{kg}$ ) (dideflasi dengan IHPB Indonesia gula pasir sektor industri, $2010=100$ )

ISCP =Harga riil eceran gula kristal putih konsumen (Rp/kg) (dideflasi dengan IHK Indonesia bahan makanan, $2010=100$ )

ILWP =Upah riil tenaga kerja sektor perkebunan (Rp/hari) (dideflasi dengan IHK Indonesia umum, $2010=100)$

IUSP $=$ Harga riil pupuk urea subsidi (Rp/kg) (dideflasi dengan IHK Indonesia umum, $2010=100$ )

IUFP =Harga riil pupuk urea $(\mathrm{Rp} / \mathrm{kg})$ (dideflasi dengan IHK Indonesia umum, $2010=100$ )

ISFA =Alokasi pupuk urea subsidi sektor perkebunan (ton)

IRFP =Harga riil gabah di tingkat petani $(\mathrm{Rp} / \mathrm{kg}$ ) (dideflasi dengan IHPB Indonesia gabah/padi sektor pertanian, $2010=100$ )
ICFP =Harga riil jagung di tingkat petani $(\mathrm{Rp} / \mathrm{kg})$ (dideflasi dengan IHPB Indonesia jagung sektor pertanian, $2010=100$ )

ISCQ $=$ Konsumsi gula kristal putih (ton) IGPC =PDB riil Indonesia per-kapita (Rp/jiwa)

INPO =Populasi penduduk Indonesia (jiwa)

IRCP =Harga riil beras di tingkat konsumen (Rp/kg) (dideflasi dengan IHK Indonesia bahan makanan, $2010=100$ )

ISMQ =Volume impor gula kristal putih Indonesia (ton)

IISM =Volume impor gula kebutuhan industri Indonesia (ton)

WOSP $=$ Harga riil gula dunia (USD/kg) (dideflasi dengan IHK dunia makanan dan minuman, $2010=$ 100)

$\mathrm{POCP}=$ Harga riil minyak goreng tingkat konsumen (Rp/kg) (dideflasi dengan IHK Indonesia bahan makanan, $2010=100$ )

HPP =HPP riil gula kristal putih tingkat petani $\mathrm{Rp} / \mathrm{kg}$ ) (dideflasi dengan IHPB Indonesia gula pasir sektor industri, $2010=100$ )

DHAP1=Dummy penerapan HAP gula kristal putih (dimana 0 jika tidak terdapat penerapan HAP gula kristal putih dan 1 jika terdapat 
penerapan HAP gula kristal putih).

DHAP2=Dummy terjadinya penurunan HAP gula kristal putih (dimana 0 jika tidak terjadi penurunan HAP gula kristal putih dan 1 jika terjadi penurunan HAP gula kristal putih).

$\mathrm{t} \quad=$ Periode waktu

\section{Metode Estimasi dan Validasi Model}

Model penawaran dan permintaan gula kristal putih Indonesia yang telah dibentuk kemudian dilakukan estimasi. Estimasi model menggunakan regresi simultan dengan data sekunder time series bulanan periode tahun 20132017 (60 bulan). Berdasarkan identifikasi model menggunakan syarat kondisi, diketahui bahwa model teridentifikasi over identified dan dapat diselesaikan menggunakan metode 2SLS.

Hasil estimasi model perlu divalidasi. Validasi model digunakan untuk menunjukkan bahwa model dapat merepresentatifkan kondisi aktual. Validasi model menggunakan nilai koefisien determinasi $\left(R^{2}\right)$ dan nilai Theil's inequality coefficient (U-Theil).

Hasil estimasi model juga dilakukan uji statistik-t. Uji statistik-t digunakan untuk menguji pengaruh setiap variabel penjelas terhadap variabel endogen. Hasil estimasi ditampilkan dalam bentuk elastisitas untuk menunjukkan pengaruh perubahan variabel penjelas terhadap variabel endogen.

\section{Metode Simulasi}

Analisis lebih lanjut, dilakukan simulasi untuk mengetahui strategi kebijakan yang dapat dilakukan untuk menurunkan harga eceran gula kristal putih. Selama periode tahun 2013-2017, pemerintah telah melakukan kebijakan harga melalui kebijakan HAP, impor gula kristal putih dan kebijakan on-farm melalui subsidi pupuk. Berdasarkan hal tersebut, dilakukan simulasi secara expost untuk mengetahui dampak kebijakan tersebut, terutama pada harga eceran gula kristal putih. Adapun simulasi dilakukan dengan skenario sebagai berikut:

a. Skenario 1 (S1), skenario tunggal penerapan HAP selama periode tahun 2013-2017.

b. Skenario 2 (S2), skenario tunggal kenaikan impor gula kristal putih sebesar $20 \%$

c. Skenario 3 (S3), skenario kombinasi kenaikan impor gula kristal putih sebesar $20 \%$ dan penerapan HAP selama periode $2013-2017$.

d. Skenario 4 (S4), skenario kombinasi penurunan harga pupuk urea 
bersubsidi sebesar $20 \%$ dan kenaikan alokasi pupuk urea bersubsidi $20 \%$.

Simulasi dilakukan berdasarkan hasil estimasi model penawaran dan permintaan gula kristal putih Indonesia. Nilai hasil simulasi ex-post tanpa adanya skenario perubahan menjadi nilai simulasi dasar (SO) sebagai nilai kontrol (benchmark). Perbandingan nilai rata-rata hasil simulasi menunjukkan dampak akibat skenario yang diterapkan selama periode 2013-2017.

\section{HASIL DAN PEMBAHASAN}

\section{Hasil Validasi Model}

Model penawaran dan permintaan gula kristal putih Indonesia terdiri dari 13 persamaan, meliputi empat persamaan identitas dan sembilan persamaan struktural. Sebanyak tujuh persamaan struktural memiliki nilai adjusted $\mathrm{R}^{2}$ lebih dari $85 \%$. Sebanyak dua persamaan struktural memiliki nilai adjusted $R^{2}$ antara $22-40 \%$. Berdasarkan nilai adjusted $R^{2}$, dapat disimpulkan bahwa variabel penjelas mampu menjelaskan keragaman variabel endogen pada persamaan struktural dengan baik.

Model penawaran dan permintaan gula kristal putih Indonesia memiliki nilai $U$-Theil tertinggi sebesar 0,298; bahwa model memiliki daya prediksi yang baik. Secara keseluruhan, disimpulkan bahwa model penawaran dan permintaan gula kristal putih Indonesia merepresentatifkan kondisi aktual dengan baik.

\section{Faktor yang Memengaruhi Harga Eceran Gula Kristal Putih}

\section{Tabel 1. Hasil Estimasi Persamaan Harga Eceran Gula Kristal Putih}

\begin{tabular}{cccc}
\hline Variabel & Parameter & Elastisitas & t-hitung \\
\hline Intercept & $-3.550,180$ & & $-2,820$ \\
SSFPt & 0,002 & 0,000 & 0,530 \\
DHAP1t & $-25,115$ & $-0,002$ & $-0,820$ \\
DHAP2t & $-13,627$ & $-0,000$ & $-0,290$ \\
ISCQt-1 & 0,006 & 0,204 & $1,820^{* *}$ \\
ISCQt-12 & 0,007 & 0,216 & $1,970^{* *}$ \\
ISPQt-1 & $-0,000$ & $-0,000$ & $-0,040$ \\
ISMQt-1 & $-0,001$ & $-0,000$ & $-0,330$ \\
IISMt-1 & $-0,000$ & $-0,009$ & $-1,560^{*}$ \\
WOSPt & $1.179,579$ & 0,075 & $3,650^{* * *}$ \\
IRCPt & 0,555 & 0,390 & $3,090^{* * *}$ \\
POCPt & $-0,071$ & $-0,078$ & $-0,740$ \\
ISCPt-1 & 0,804 & & $10,340^{* * *}$ \\
ISCPt-12 & 0,197 & & $2,770^{* * *}$ \\
\hline Jumlah sampel $(\mathrm{n})$ & 60 & $\mathrm{R}^{2}$ & 0,936 \\
& & adjusted $\mathrm{R}^{2}$ & 0,918 \\
\hline
\end{tabular}

\footnotetext{
Keterangan : ${ }^{* * *}$ signifikan pada $\alpha=5 \%$

** signifikan pada $\alpha=10 \%$

* signifikan pada $\alpha=15 \%$
} 
Model yang telah divalidasi signifikan terhadap harga eceran gula selanjutnya dilakukan uji statistik-t. Fokus penelitian adalah analisis harga eceran gula kristal putih. Sehingga hasil yang ditampilkan adalah hasil estimasi dan nilai uji statistik-t pada harga eceran gula kristal putih Indonesia. Terdapat variabel penjelas yang tidak signifikan berpengaruh terhadap harga eceran gula kristal putih (Tabel 1). Namun, penelitian ini juga menganalisis hasil berdasarkan tanda dan besaran elastisitas dari hasil estimasi.

\section{Harga Lelang Gula Kristal Putih}

Perubahan harga lelang gula kristal putih tidak berpengaruh secara

kristal putih. Elastisitas perubahan harga lelang gula kristal putih inelastis positif; dengan nilai yang sangat kecil.

Harga eceran dan harga lelang gula kristal putih berfluktuasi cenderung mengalami peningkatan harga pada periode 2012-2017. Perkembangan harga lelang dan harga eceran gula kristal putih tidak selalu searah (Gambar 3). Hal ini menyebabkan perubahan harga lelang gula kristal putih tidak berpengaruh secara signifikan terhadap harga eceran gula kristal putih, namun tetap memiliki nilai koefisien dan elastisitas yang positif.

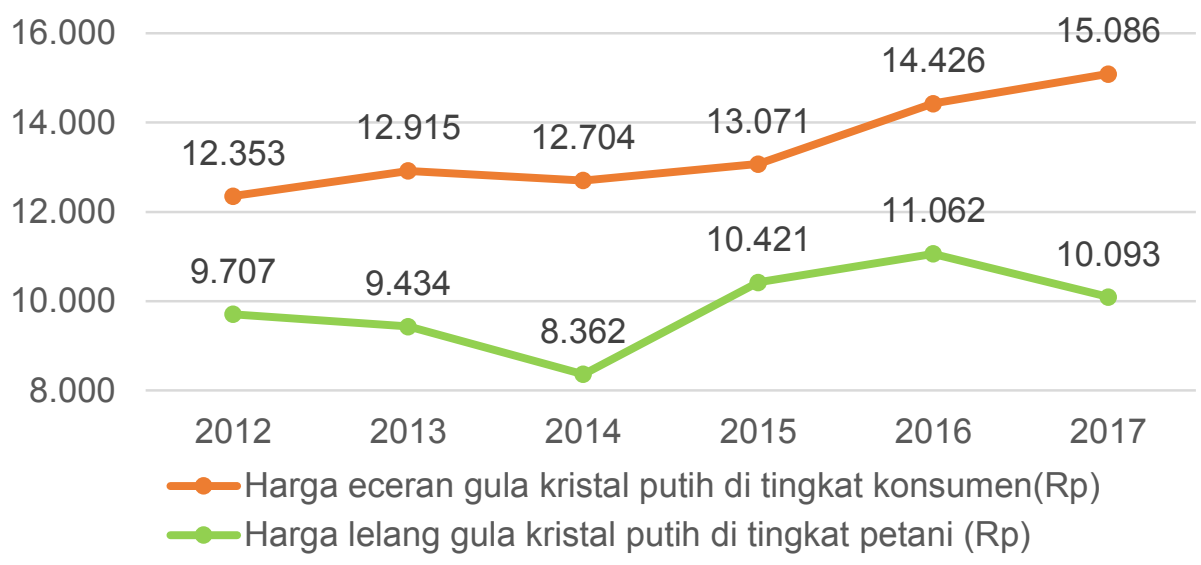

\section{Gambar 3. Perkembangan Harga Gula Kristal Putih Indonesia Tahun 2012-2017}

Sumber : BPS (2013), BPS (2014a), BPS (2015a), BPS (2016a), BPS (2017a), BPS (2018a), Kementerian Perdagangan Republik Indonesia (2019)

\section{HAP Gula Kristal Putih}

Penerapan HAP gula kristal putih tidak berpengaruh secara signifikan terhadap harga eceran gula kristal putih.
Sedangkan penurunan HAP gula kristal putih juga tidak berpengaruh secara signifikan terhadap harga eceran gula kristal putih. Hal ini karena HAP tidak 
ditetapkan sebagai harga tertinggi (ceiling price) namun sebagai harga acuan.

Pemerintah tidak dapat memaksa harga eceran gula kristal putih berada di bawah HAP. Namun menjadi alarm harga, bahwa secara nasional harga eceran gula kristal putih tertinggi adalah Rp 12.500,00/kg. Alarm harga tersebut juga menjadi salah satu indikasi untuk dilakukannya stabilisasi gula kristal putih melalui penggunaan cadangan gula pemerintah maupun impor gula kristal putih. Hal tersebut sesuai dengan Peraturan Pemerintah Republik Indonesia nomor 17 tahun 2015 dan Permendag RI Nomor 117/MDAG/PER/12/2015.

\section{Konsumsi Gula Kristal Putih}

Konsumsi gula kristal putih pada periode sebelumnya berpengaruh secara signifikan (pada $\alpha=10 \%$ ) terhadap harga eceran gula kristal putih. Elastisitas konsumsi gula kristal putih tergolong elastis positif. Nilai elastisitas konsumsi gula kristal putih periode satu tahun sebelumnya lebih besar dibandingkan nilai elastisitas konsumsi gula kristal putih periode satu bulan sebelumnya. Sehingga, pembentukan harga riil eceran gula kristal putih lebih responsif terhadap perubahan konsumsi gula kristal putih pada periode jangka panjang (satu tahun sebelumnya) dibandingkan pada periode jangka pendek (satu bulan sebelumnya). Hal ini dikarenakan adanya siklus perubahan konsumsi masyarakat Indonesia (terutama pada saat hari raya keagamaan) yang menyebabkan naik turunnya harga eceran gula kristal putih.

\section{Produksi Gula Kristal Putih}

Budidaya tebu menjadi sumber utama industri gula di Indonesia (Lestari et al., 2016). Namun, produksi gula kristal putih pada periode satu bulan sebelumnya tidak berpengaruh secara signifikan terhadap harga eceran gula kristal putih. Hal ini juga mengindikasikan harga eceran gula kristal putih tidak responsif terhadap perubahan produksi pada musim giling dan di luar musim giling. Elastisitas perubahan produksi gula kristal putih tergolong inelastis negatif, dengan nilai yang sangat kecil. Perkembangan harga eceran gula kristal putih terjadi seiring turunnya produksi gula kristal putih.

\section{Impor Gula Kristal Putih dan Harga Gula Dunia}

Impor gula kristal putih tidak berpengaruh secara signifikan terhadap harga eceran gula kristal putih, dengan elastisitas tergolong inelastis negatif. Sedangkan impor gula kebutuhan 
industri (gula kristal mentah dan gula kristal rafinasi) berpengaruh secara signifikan (pada $\alpha=15 \%$ ) terhadap harga eceran gula kristal putih, dengan elastisitas tergolong inelastis negatif. Nilai elastisitas impor gula kebutuhan industri secara absolut lebih tinggi dibandingkan nilai elastisitas impor gula kristal putih.

Harga gula dunia berpengaruh secara signifikan (pada $\alpha=5 \%$ ) terhadap harga eceran gula kristal putih. Elastisitas perubahan harga gula dunia gula kristal putih tergolong inelastis positif. Harga gula dunia lebih rendah dibandingkan harga gula kristal putih dalam negeri. Pengaruh signifikan harga gula dunia terhadap harga eceran terjadi akibat adanya impor gula kristal putih.

Meskipun hasil estimasi menunjukkan pengaruh yang tidak signifikan, impor gula kristal putih dapat menurunkan harga eceran gula kristal putih. Melalui impor, harga eceran gula kristal putih dapat turun mengikuti harga dunia. Ketidakseimbangan antara permintaan dan produksi gula kristal putih Indonesia diselesaikan dengan kebijakan impor (Kurniasari et al., 2015). Namun, jumlah impor gula kristal putih sangat kecil (Tabel 2).

Tabel 2. Impor Gula Indonesia Tahun 2012-2017

\begin{tabular}{ccc}
\hline Tahun & Impor gula kristal putih (ton) & Impor gula kebutuhan industri (ton) \\
\hline 2012 & 25.460 & 2.790 .480 \\
2013 & 500 & 3.343 .803 \\
2014 & 31.979 & 2.933 .823 \\
2015 & 5.069 & 3.369 .941 \\
2016 & 15.838 & 4.746 .047 \\
2017 & 11.847 & 4.375 .586 \\
\hline
\end{tabular}

Sumber : ITC (2019b), ITC (2019a), ITC (2019c), ITC (2019d), ITC (2019e), ITC (2019f) dan ITC $(2019 \mathrm{~g})$

Jumlah impor gula kristal putih yang kecil tersebut menyebabkan impor gula kristal putih tidak dapat menurunkan harga gula kristal putih secara signifikan. Impor gula kristal putih dibatasi oleh pemerintah untuk melindungi petani tebu dalam negeri. Pengaturan jumlah impor gula kristal putih diatur berdasarkan Permendag RI Nomor 117/M-DAG/PER/12/2015.

Selain itu, impor gula Indonesia sebagian besar adalah untuk pasar industri (gula kristal rafinasi dan gula kristal mentah). Sedangkan untuk pasar konsumsi rumah tangga (gula kristal putih) hanya sebagian kecil (Tabel 2). 
Meski ada pembatasan perdagangan gula dalam negeri, dengan nilai elastisitas impor gula kebutuhan industri yang lebih tinggi dibandingkan nilai elastisitas impor gula kristal putih, mengindikasikan kebocoran gula industri pada pasar gula kristal putih masih terjadi.

\section{Harga Bahan Pangan Pokok Lainnya}

Harga beras di tingkat konsumen berpengaruh secara signifikan ( $\alpha=5 \%$ ) terhadap harga eceran gula kristal putih, dengan elastisitas tergolong inelastis positif. Sedangkan harga minyak goreng di tingkat konsumen tidak berpengaruh secara signifikan terhadap harga eceran gula kristal putih. Nilai elastisitas harga beras meskipun tergolong inelastis, namun secara absolut tertinggi dibandingkan nilai elastisitas variabel lainnya (Tabel 1).

Kenaikan harga beras berpotensi membentuk ekspektasi inflasi. Beras sebagai pangan pokok memiliki nilai strategis dalam ekonomi dan politik di Indonesia (Respatiadi \& Nabila, 2018). Beras memiliki karakteristik perubahan harga yang memengaruhi dan memicu kondisi kenaikan harga barang lainnya. Hal ini yang menjadi dasar penetapan beras dan gula sebagai bahan pangan pokok (Perpres RI Nomor 71 Tahun 2015).

\section{Harga Eceran Gula Kristal Putih Periode Sebelumnya}

Harga riil eceran gula kristal putih pada periode satu bulan sebelumnya dan periode satu tahun sebelumnya berpengaruh positif secara signifikan. Hal ini mengindikasikan bahwa tren kenaikan harga eceran gula kristal putih merupakan respon positif secara signifikan perubahan kondisi pada periode sebelumnya. Tren harga eceran gula kristal putih menunjukkan kenaikan harga pada periode 2012-2017 (Gambar 1).

\section{Analisis Strategi Kebijakan Terkait Harga Eceran Gula Kristal Putih}

Simulasi dilakukan untuk mengetahui strategi kebijakan yang dapat dilakukan untuk menurunkan harga eceran gula kristal putih. Pengamatan difokuskan pada perubahan harga eceran gula kristal putih akibat skenario simulasi (Tabel 3 ). 
Tabel 3. Hasil Simulasi Dampak Skenario Kebijakan

\begin{tabular}{|c|c|c|c|c|c|}
\hline \multirow{2}{*}{ Deskripsi Variabel } & \multirow{2}{*}{ Variabel } & \multicolumn{4}{|c|}{ Skenario (\% perubahan) } \\
\hline & & S1 & S2 & S3 & S4 \\
\hline Harga eceran gula kristal putih & & $-0,420$ & $-0,005$ & $-0,424$ & 0,000 \\
\hline \multicolumn{6}{|c|}{$\begin{aligned} \text { Keterangan : Skenario } 1(\mathrm{~S} 1)= & \text { Skenario tunggal penerapan HAP selama periode } 2013-2017 . \\
\text { Skenario } 2(\mathrm{~S} 2)= & \text { Skenario tunggal kenaikan impor gula kristal putih sebesar } 20 \% . \\
\text { Skenario } 3(\mathrm{~S} 3)= & \text { Skenario kombinasi kenaikan impor gula kristal putih sebesar } 20 \% \text { dan } \\
& \text { penerapan HAP selama periode } 2013-2017 . \\
\text { Skenario } 4(\mathrm{~S} 4)= & \text { Skenario kombinasi penurunan harga pupuk urea bersubsidi sebesar } \\
& 20 \% \text { dan kenaikan alokasi pupuk urea bersubsidi sebesar } 20 \% .\end{aligned}$} \\
\hline
\end{tabular}

Hasil simulasi Skenario 1 menunjukkan penurunan pada harga eceran gula kristal putih. Hasil analisis menunjukkan bahwa penerapan HAP gula kristal putih tidak berpengaruh secara signifikan terhadap harga eceran gula kristal putih (Tabel 1). Meskipun demikian, penerapan HAP gula kristal putih memiliki nilai elastisitas tergolong inelastis negatif. Sehingga melalui penerapan HAP gula kristal putih, harga eceran gula kristal putih mengalami penurunan.

Skenario 2 menunjukkan dampak kenaikan impor gula kristal putih pada harga eceran gula kristal putih. Skenario 2 menyebabkan penurunan harga eceran gula kristal putih. Penurunan harga eceran gula kristal putih sangat kecil, hal ini dikarenakan elastisitas impor gula kristal putih tergolong inelastis negatif, dengan nilai yang sangat kecil. Meskipun demikian, dapat disimpulkan bahwa pemerintah dapat menambah jumlah impor gula kristal putih ketika terjadi kenaikan harga eceran gula kristal putih.

Skenario 3 menunjukkan dampak penerapan HAP gula kristal putih dengan peningkatan impor gula kristal putih. Secara terpisah, penerapan HAP gula kristal putih dan peningkatan impor gula kristal putih menyebabkan penurunan harga eceran gula kristal putih. Kombinasi kedua kebijakan tersebut pada Skenario 3 menyebabkan penurunan harga eceran gula kristal putih terbesar dibandingkan skenario kebijakan lainnya.

HAP gula kristal putih (sesuai Peraturan Menteri Perdagangan Republik Indonesia Nomor 63/M-DAG/PER/9/2016 dan direvisi melalui Peraturan Menteri Perdagangan Republik Indonesia Nomor 27/M-DAG/PER/5/2017) menjadi acuan bagi Pemerintah untuk melakukan intervensi langsung pada pasar. Berdasarkan Peraturan Presiden 
Republik Indonesia Nomor 71 Tahun 2015 penetapan HAP gula kristal putih tergolong sebagai penetapan harga eceran tertinggi dalam rangka operasi pasar untuk barang kebutuhan pokok (Hermanto, 2015).

Ketika harga eceran gula kristal putih berada di atas HAP, Menteri dapat menugaskan BUMN terkait untuk melakukan penjualan gula kristal putih di tingkat konsumen sesuai dengan HAP gula kristal putih yang bertujuan menurunkan harga gula kristal putih di tingkat konsumen. Peraturan Presiden Republik Indonesia Nomor 48 Tahun 2016 menetapkan stabilisasi harga pada tingkat konsumen dilaksanakan melalui pelaksanaan operasi pasar menggunakan cadangan pangan pemerintah dengan harga tertinggi sama dengan harga HAP. Cadangan pangan gula kristal putih berasal dari produksi dalam negeri maupun impor gula kristal putih (Erwidodo, 2015).

Sehingga upaya stabilisiasi harga eceran gula kristal putih harga eceran gula kristal putih masih membutuhkan kebijakan HAP, namun juga harus terintegrasi dengan pengelolaan impor (Hermanto, 2015). Berdasarkan konsep ketahanan pangan, sumber pangan untuk memenuhi kebutuhan pangan masyarakat tidak menjadi isu penting.
Sepanjang masyarakat di suatu negara dapat memperoleh pangan dengan mudah dan harga terjangkau sepanjang waktu (Suryana, 2015).

Subsidi pupuk merupakan langkah pemerintah untuk meningkatkan produksi gula kristal putih agar dapat menekan harga eceran gula kristal putih. Selama ini besaran HET pupuk relatif tidak banyak berubah (Susilowati, 2018). Salah satu upaya untuk memenuhi tujuan tersebut adalah meningkatkan alokasi anggaran subsidi pupuk (Rustiani, 2018). Namun, produksi gula kristal putih tidak berpengaruh signifikan terhadap harga eceran gula kristal putih, dengan nilai elastisitas yang sangat kecil (Tabel 1). Sehingga, hasil simulasi menunjukkan bahwa penurunan harga dan kenaikan alokasi pupuk urea bersubsidi (Skenario 4) tidak menyebabkan perubahan pada harga eceran gula kristal putih.

\section{KESIMPULAN DAN REKOMENDASI KEBIJAKAN}

Faktor yang berpengaruh secara signifikan pada harga eceran gula kristal putih adalah konsumsi gula kristal putih, impor gula kebutuhan industri, harga gula dunia, harga beras di tingkat konsumen dan harga eceran gula kristal putih pada periode sebelumnya. Harga beras di tingkat konsumen merupakan 
variabel yang paling berpengaruh terhadap pembentukan harga gula kristal putih.

Skenario kebijakan yang dapat menurunkan harga eceran gula kristal putih adalah penerapan HAP gula kristal putih yang terintegrasi dengan kenaikan impor gula kristal putih. Kebijakan HAP gula kristal putih dapat diterapkan sebagai harga acuan yang terintegrasi dengan pengelolaan impor. Peningkatan jumlah impor gula kristal putih dapat menurunkan harga eceran gula kristal putih. Pemerintah dapat menambah jumlah impor gula kristal putih ketika terjadi kenaikan harga eceran melebihi HAP gula kristal putih.

\section{UCAPAN TERIMA KASIH}

Penulis mengucapkan terima kasih kepada seluruh redaksi Buletin Ilmiah Litbang Perdagangan, Mitra Bestari dan seluruh pihak terkait dalam penulisan karya ini atas seluruh kesempatan, kontribusi dan bantuan yang diberikan.

\section{DAFTAR PUSTAKA}

Badan Pusat Statistik (BPS). (2013). Statistik Harga Konsumen Perdesaan Kelompok Makanan 2013. Badan Pusat Statistik. https://www.bps.go.id/publication/201 3/04/24/644206aa74be47e04fa1795f /statistik-harga-konsumenperdesaan-kelompok-makanan-2013

Badan Pusat Statistik (BPS). (2014a). Statistik Harga Konsumen Perdesaan
Kelompok Makanan (Data 2013).

Badan Pusat Statistik.

https://www.bps.go.id/publication/201

4/04/30/8f9ffdcfe67e7182adadd3a7/s tatistik-harga-konsumen-perdesaan-

kelompok-makanan-data-2013-

Badan Pusat Statistik (BPS). (2014b). Statistik Tebu Indonesia 2013. Badan Pusat Statistik https://www.bps.go.id/publication/201 4/07/25/0bc7453a643e1378bb00b59 4/statistik-tebu-indonesia-2013

Badan Pusat Statistik (BPS). (2015a). Statistik Harga Konsumen Perdesaan Kelompok Makanan 2014. Badan Pusat Statistik. https://www.bps.go.id/publication/201 5/04/30/7f8c6d75625766ca9c4facd7/ statistik-harga-konsumen-perdesaankelompok-makanan2014

Badan Pusat Statistik (BPS). (2015b). Statistik Tebu Indonesia 2014. Badan Pusat Statistik. https://www.bps.go.id/publication/201 5/07/30/6b48be9594d58e0fbc62275f/ statistik-tebu-indonesia-2014

Badan Pusat Statistik (BPS). (2016a). Statistik Harga Konsumen Perdesaan Kelompok Makanan 2015. Badan Pusat Statistik. https://www.bps.go.id/publication/201 6/04/29/9e2cbef6c6f42442967fd2d1/ statistik-harga-konsumen-perdesaankelompok-makanan-2015

Badan Pusat Statistik (BPS). (2016b). Statistik Tebu Indonesia 2015. Badan Pusat Statistik. https://www.bps.go.id/publication/201 6/09/01/3c6a33a29d68f1f5d82f32a9/ statistik-tebu-indonesia-2015

Badan Pusat Statistik (BPS). (2017a). Statistik Harga Konsumen Perdesaan Kelompok Makanan 2016. Badan Pusat Statistik. https://www.bps.go.id/publication/201 7/05/05/66188156a600d85390e3e52 4/statistik-harga-konsumenperdesaan-kelompok-makanan-2016

Badan Pusat Statistik (BPS). (2017b). Statistik Tebu Indonesia 2016. Badan 
Pusat

Statistik.

https://www.bps.go.id/publication/201

7/11/10/d1ade8b3b28b2f118c3968d7

/statistik-tebu-indonesia-2016

Badan Pusat Statistik (BPS). (2018a). Statistik Harga Konsumen Perdesaan Kelompok Makanan 2017. Badan Pusat Statistik. https://www.bps.go.id/publication/201 8/05/07/a3e870a0198485cfb9d7fa12/ statistik-harga-konsumen-perdesaankelompok-makanan-2017

Badan Pusat Statistik (BPS). (2018b). Statistik Tebu Indonesia 2017. Badan Pusat Statistik. https://www.bps.go.id/publication/201 8/11/13/5202a47197d21c1d9c0b3b2 e/statistik-tebu-indonesia-2017

Erwidodo. (2015). Kebijakan impor, cadangan pangan, stabilisasi harga dan ketahanan pangan nasional berkemandirian. In E. Pasandaran, $\mathrm{M}$. Rachmat, Hermanto, M. Ariani, Sumedi, K. Suradisastra, \& Haryono (Eds.), Memperkuat Kemampuan Swasembada Pangan (pp. 172-191). IAARD Press.

Fajrin, A. El, Hartono, S., \& Waluyati, L. R. (2015). Permintaan gula rafinasi pada industri makanan minuman dan farmasi di Indonesia. Agro Ekonomi, 26(2), 150-158. https://doi.org/doi.org/10.22146/agro ekonomi.17267

Hermanto. (2015). Stabilisasi harga pangan pokok dalam rangka kemandirian pangan nasional. In E. Pasandaran, M. Rachmat, Hermanto, M. Ariani, Sumedi, K. Suradisastra, \& Haryono (Eds.), Memperkuat Kemampuan Swasembada Pangan (pp. 136-146). IAARD Press.

International Trade Center (ITC). (2019a). List of Supplying Markets for a Product Imported by Indonesia, Product: 1701910000 Cane/Beet Sugar, Added Flavour/Color. https://www.trademap.org/tradestat/C ountry_SelCountry_MQ_TS.aspx?nv $\mathrm{pm}=1 \% 7 \mathrm{C} 360 \% 7 \mathrm{C} \% 7 \mathrm{C} \% 7 \mathrm{C} \% 7 \mathrm{C} 17$
01910000\%7C\%7C\%7C8\%7C1\%7C 1\%7C1\%7C2\%7C3\%7C2\%7C2\%7C 1

International Trade Center (ITC). (2019b). List of Supplying Markets for a Product Imported by Indonesia, Product: 1701999000 Other Cane or Beet Sugar, \& Chemically Pure Sucrose, in Sold Form. https://www.trademap.org/tradestat/C ountry_SelCountry_MQ_TS.aspx?nv $\mathrm{pm}=1 \% 7 \mathrm{C} 360 \% 7 \mathrm{C} \% 7 \mathrm{C} \% 7 \mathrm{C} \% 7 \mathrm{C} 17$ 01999000\%7C\%7C\%7C8\%7C1\%7C 1\%7C1\%7C2\%7C3\%7C2\%7C2\%7C 1

International Trade Center (ITC). (2019c). List of Supplying Markets for a Product Imported by Indonesia Product: 1701120000 Beet Sugar, Not Added Flavour/Color. https://www.trademap.org/tradestat/C ountry_SelCountry MQ TS.aspx?nv $\mathrm{pm}=1 \% 7 \mathrm{C} 360 \% 7 \mathrm{C} \% 7 \mathrm{C} \% 7 \mathrm{C} \% 7 \mathrm{C} 17$ 01120000\%7C\%7C\%7C8\%7C1\%7C 1\%7C1\%7C2\%7C3\%7C2\%7C2\%7C 1

International Trade Center (ITC). (2019d). List of Supplying Markets for a Product Imported by Indonesia Product: 1701130000 Cane Sugar, Raw, Not Added Flavour/Colour. https://www.trademap.org/tradestat/C ountry_SelCountry MQ TS.aspx?nv $\mathrm{pm}=1 \% 7 \mathrm{C} 360 \% 7 \mathrm{C} \% 7 \mathrm{C} \% 7 \mathrm{C} \% 7 \mathrm{C} 17$ $01130000 \% 7 \mathrm{C} \% 7 \mathrm{C} \% 7 \mathrm{C} 8 \% 7 \mathrm{C} 1 \% 7 \mathrm{C}$ 1\%7C1\%7C2\%7C3\%7C2\%7C2\%7C 1

International Trade Center (ITC). (2019e). List of Supplying Markets for a Product Imported by Indonesia Product: 1701140000 Other Cane Sugar, Raw, Not Added Flavour. https://www.trademap.org/tradestat/C ountry_SelCountry MQ TS.aspx?nv $\mathrm{pm}=1 \% 7 \mathrm{C} 360 \% 7 \mathrm{C} \% 7 \mathrm{C} \% 7 \mathrm{C} \% 7 \mathrm{C} 17$ 01140000\%7C\%7C\%7C8\%7C1\%7C $1 \% 7 \mathrm{C} 1 \% 7 \mathrm{C} 2 \% 7 \mathrm{C} 3 \% 7 \mathrm{C} 2 \% 7 \mathrm{C} 2 \% 7 \mathrm{C}$ 1

International Trade Center (ITC). (2019f). List of Supplying Markets for a Product Imported by Indonesia 
Product: 1701991100 Refined Sugar, White.

https://www.trademap.org/tradestat/C ountry_SelCountry_MQ_TS.aspx?nv $\mathrm{pm}=1 \% 7 \mathrm{C} 360 \% 7 \mathrm{C} \% 7 \mathrm{C} \% 7 \mathrm{C} \% 7 \mathrm{C} 17$ 01991100\%7C\%7C\%7C8\%7C1\%7C 1\%7C1\%7C2\%7C3\%7C2\%7C2\%7C 1

International Trade Center (ITC). (2019g). List of Supplying Markets for a Product Imported by Indonesia Product: 1701991900 Other Refined Sugar.

https://www.trademap.org/tradestat/C ountry_SelCountry_MQ_TS.aspx?nv $\mathrm{pm}=1 \% 7 \mathrm{C} 360 \% 7 \mathrm{C} \% 7 \mathrm{C} \% 7 \mathrm{C} \% 7 \mathrm{C} 17$ 01991900\%7C\%7C\%7C8\%7C1\%7C 1\%7C1\%7C2\%7C3\%7C2\%7C2\%7C 1

Kementerian Perdagangan Republik Indonesia. (2019). Grafik Perkembangan BPP, HPP, dan Harga Lelang Tahun 2007-2018. Kementerian Perdagangan Republik Indonesia.

Keputusan Menteri Perindustrian dan Perdagangan Republik Indonesia Nomor: $\quad 334 / M P P / K e p / 5 / 2004$ Tentang Perubahan Atas Keputusan Menteri Perindustrian dan Perdagangan Nomor 61/MPP/Kep/2/2004 Tentang

Perdagangan Gula Antar Pulau. 2004. Jakarta.

Kurniasari, R. I., Darwanto, D. H., \& Widodo, S. (2015). Permintaan Gula Kristal Mentah Indonesia. IImu Pertanian, 18(1), 24-30. https://doi.org/https://doi.org/10.2214 6/ipas.6173

Lakollo, E. M. (2015). Kebijakan harga serta dampaknya terhadap ketahanan pangan. In E. Pasandaran, M. Rachmat, Hermanto, M. Ariani, Sumedi, K. SUradisastra, \& Haryono (Eds.), Memperkuat Kemampuan Swasembada Pangan (pp. 192-202). IAARD Press.

Lestari, E. K., Fauzi, A., Hutagaol, M. P., \& Hidayat, A. (2016). Analysis of sugarcane farming in the sugar mill District Semboro Jember, Indonesia : a data envelopment analysis application. International Journal of Sciences: Basic and Applied Research (IJSBAR), 25(2), 157-171. http://gssrr.org/index. php?journal=Jo urnalOfBasicAndApplied\&page $=$ articl e\&op=view\&path $\% 5 B \% 5 D=5165$

Mankiw, G. (2019). Pengantar Ekonomi Mikro (7th ed.). Salemba Empat.

Nuryati, Y., Wicaksena, B., \& Prabowo, D. W. (2019). Dampak Penerapan Harga Acuan Pembelian (HAP) Gula di Tingkat Eceran Terhadap Harga Gula Petani dan Stabilitas Harga Gula. Buletin IImiah Litbang Perdagangan, 13(1), $\quad$ 137-162. https://doi.org/https://doi.org/10.3090 8/bilp.v13i1.354

Pakpahan, F. P. M. (2017). Pengelolaan Tanaman Tebu (Saccharum Officinarum L.) di Wilayah Kerja PG Madukismo, PT Madubaru, Yogyakarta dengan Aspek Khusus Korelasi Pemupukan dengan Produktivitas [Institut Pertanian Bogor].

https://repository.ipb.ac.id/handle/123 456789/89804

Peraturan Menteri Perdagangan Republik Indonesia Nomor 27/MDAG/PER/5/2017 Tentang Penetapan Harga Acuan Pembelian di Petani dan Harga Acuan Penjualan di Konsumen. 2017. Jakarta.

Peraturan Menteri Perdagangan Republik Indonesia Nomor 63/MDAG/PER/9/2016 Tentang Penetapan Harga Acuan Pembelian di Petani dan Harga Acuan Penjualan di Konsumen. 2016. Jakarta.

Peraturan Menteri Perdagangan Republik Indonesia Nomor 117/MDAG/PER/12/2015 Tentang Impor Gula. 2015. Jakarta.

Peraturan Presiden Republik Indonesia Nomor 48 Tahun 2016 Tentang Penugasan Kepada Perusahaan Umum (Perum) Bulog dalam Rangka 
Ketahanan Pangan Nasional. 2016. Jakarta.

Peraturan Presiden Republik Indonesia Nomor 71 Tahun 2015 Tentang Penetapan dan Penyimpanan Barang Kebutuhan Pokok dan Barang Penting. 2015. Jakarta.

Pusat Kebijakan Perdagangan Dalam Negeri. (2015). Laporan Akhir Analisis Lelang Gula PTPN/Petani dalam Rangka Stabilisasi Harga.

Rahardja, P., \& Manurung, M. (2014). Pengantar Ilmu Ekonomi (Mikroekonomi dan Makroekonomi) Edisi Ketiga (3rd ed.). Lembaga Penerbit Fakultas Ekonomi Universitas Indonesia.

Rahman, M. E., Sinaga, B. M., Harianto, N., \& Susilowati, S. H. (2018). Kebijakan Dukungan Domestik untuk Menetralisir Dampak Negatif Penurunan Tarif Impor Terhadap Industri Gula Indonesia. Jurnal Agro Ekonomi, 36(2), 91-112. https://doi.org/http://dx.doi.org/10.210 82/jae.v36n2.2018.91-112

Respatiadi, H., \& Nabila, H. (2018). Policy Options to Lower Rice Prices in Indonesia. Pilihan Kebijakan Untuk Menurunkan Harga Beras di Indonesia. Bulletin IImiah Litbang Perdagangan. https://doi.org/10.30908/bilp.v12i1.26 2

Rustiani, F. (2018). Strategi Kebijakan Subsidi Pupuk Terhadap Pendapatan Petani. Institut Pertanian Bogor.

Sa'diyah, C., Muhaimin, A. W., \& Suhartini. (2014). Faktor-faktor yang mempengaruhi kinerja ekonomi gula kristal di Indonesia. Habitat, XXV(2), 70-77.

https://habitat.ub.ac.id/index.php/habi tat/article/view/143

Saputri, N. K., \& Respatiadi, H. (2018). Reformasi Kebijakan untuk Menurunkan Harga Gula di Indonesia (p. 36). Center for Indonesian Policy Studies. https://repository.cips- indonesia.org/media/270473reformasi-kebijakan-untukmenurunkan-har-8c9b5664.pdf

Sayaka, B., \& Adhie, S. (2016). Stabilisasi Harga Pangan Nonberas di Malaysia. Forum Penelitian Agro Ekonomi, 34(1), 71-86. https://doi.org/http://dx.doi.org/10.210 82/fae.v34n1.2016.71-86

Suryana, A. (2015). Cadangan pangan mendukung stabilitas harga dan penanganan darurat pangan. In $\mathrm{E}$. Pasandaran, M. Rachmat, Hermanto, M. Ariani, Sumedi, K. Suradisastra, \& Haryono (Eds.), Memperkuat Kemampuan Swasembada Pangan (pp. 147-171). IAARD Press.

Susila, W. R., \& Sinaga, B. M. (2005). Analisis kebijakan industri gula Indonesia. Jurnal Agro Ekonomi, 23(1), 30-53. https://doi.org/10.21082/jae.v23n1.20 05.30-53

Susilo, D., \& Yuniati, S. (2016). Kebijakan perdagangan gula Indonesia dan kesejahteraan petani tebu. In $\mathrm{E}$. Wahyudi \& N. Rahmawati (Eds.), Pemberdayaan dan Inovasi Tata Kelola Pemerintahan Daerah dan Desa (pp. 89-101). Pena Salsabila. http://repository.unej.ac.id/handle/12 $3456789 / 79333$

Susilowati, S. H. (2018). Alternatif Penyempurnaan Kebijakan Subsidi Pupuk. In T. Sudaryanto, Syahyuti, E. Suryani, \& E. Ariningsih (Eds.), Ragam Pemikiran Menjawab Isu Aktual Pertanian (1st ed., pp. 47-78). IAARD Press. http://pse.litbang.pertanian.go.id/ind/i ndex.php/layananpublik/publikasi/buku-tematik/281ragam-pemikiran-menjawab-isuaktual-pertanian

Undang-Undang Republik Indonesia Nomor 18 Tahun 2012 Tentang Pangan. 2012. Jakarta.

Yusuf, Y., Aulia, A. F., \& Artadi, S. M. (2010). Permintaan Gula Pasir di Indonesia. Jurnal Ekonomi 
Universitas Indonesia, 18(03).

https://ejournal.unri.ac.id/index.php/J

E/article/view/768 